\title{
OBSERVATIONS ON CEREBRAL CYTOMEGALIC INCLUSION DISEASE OF THE FOETUS AND NEWBORN
}

\author{
BY \\ G. B. ELLIOTT and K. A. ELLIOTT \\ From the Department of Clinical Pathology, Calgary General Hospital, Alberta, Canada
}

(RECEIVED FOR PUBLICATION MAY 24, 1961)

We report observations on three cases of cytomegalic inclusion disease. In one, advanced periventricular necrosis of brain with calco-siderosis antedated purpuric and icteric manifestations of the disease which showed shortly after birth at eight months gestation. In the second, advanced periventricular cerebral necrosis had occurred by the sixth month of foetal life, while the third was diagnosed at birth and the disease halted during steroid therapy.

\section{Case Reports}

Case 1. After an uneventful pregnancy, a 20-year-old immigrant primigravida from Hungary delivered a baby girl, four weeks prematurely, weighing $4 \mathrm{lb}$. $8 \mathrm{oz}$. Immediately after birth the child became cyanosed. Within hours a generalized ecchymotic rash appeared and there was mild dyspnoea. The liver was palpable one inch and the spleen half an inch below the costal margins. Cord blood bilirubin was $6.6 \mathrm{mg} . / 100 \mathrm{ml}$., $\mathrm{Hb} 12 \mathrm{~g}$./100 ml., the infant's blood film showed only occasional normoblasts and the one-stage prothrombin time was 60 seconds (control 15 seconds). Maternal blood Wassermann reaction was negative. A tentative diagnosis of haemorrhagic disease of the newborn was made and vitamin $\mathrm{K}$ analogue $5 \mathrm{mg}$. was given intramuscularly, with a $50 \mathrm{ml}$. transfusion of group $\mathrm{O} \mathrm{Rh}$ negative unmatched blood. The child's condition did not improve and she died nine hours later.

At autopsy multiple petechiae were seen scattered over the cerebrum and choroid plexuses, with recent blood staining of cerebrospinal fluid. No microgyria was noted. On section the ependymal surface of the lateral ventricles was irregularly replaced by rusty yellow shaggy slough. The immediate subependymal zone showed uniform bright yellow discoloration and softening, seldom more than $1 \mathrm{~mm}$. in thickness. Irregular stellate yellow zones of necrosis up to $7 \mathrm{~mm}$. long were also scattered in isolated fashion throughout the centrum ovale (Fig. 1). Rarely did these form tiny pseudocysts, nor were they discharging into the lateral ventricles. Such changes were prominent in frontal and temporal horns, with haemorrhage and slough replacing the pes hippocampi. The remainder of the brain was grossly normal. Radiographs of cerebral slices showed fine calcification defining the periventricular necrosis (Fig. 2). Microscopically the subependymal granular necrosis was almost laminar, with practically no host reaction (Fig. 3). Histochemical calcosiderosis was present in the necrotic areas. Calcification of myelinated fibres appeared to be the initial necrotic change and mimicked fungal hyphae (Fig. 4). Cytomegalic inclusion bodies were infrequent, but present, in glial and endothelial cells in these regions. The ependymal ulceration appeared secondary to the underlying softening. Less marked necrosis was seen in the walls of the third ventricle and the fourth ventricle. The cerebellum and pons were intact. A few cytomegalic inclusions were found in glial cells throughout the medulla, except in olivary nuclei. Optic nerves and retina were intact. Cytomegalic inclusions were prominent in otherwise intact parotids (Fig. 5) and pancreatic ducts, with smaller numbers in anterior pituitary, in cervical lymph nodes, in lungs and in hepatic cells with separate irregular areas of focal necrosis. Large numbers were found in renal convoluted tubules with interstitial nephritis (Fig. 6). Careful search revealed none in any of the other tissues. Extensive terminal meconium blockade of the lungs was present. Refrigerated tissue from the centrum ovale was sent by air-mail to the Virus Laboratories of the University of Manitoba. No virus was isolated on tissue culture, and no evidence of toxoplasmosis was found on mouse inoculation.

Fifteen months later this mother delivered a normal full-term female child. Both showed normal urine sediments on serial microscopic examinations for inclusion bodies. This second child has developed normally.

Case 2. A healthy primigravida, 20 years of age, unexpectedly delivered a male child after $5 \frac{1}{2}$ months of pregnancy; the delivery was uncomplicated. The birth weight was $3 \mathrm{lb}$. and cord blood bilirubin $2.7 \mathrm{mg} . / 100 \mathrm{ml}$. Both mother and child were group A Rh positive and the mother's blood Wassermann reaction was negative. The child was drowsy for six days when slight jaundice was first detected. Thereafter he remained listless, he regurgitated feeds, and he lost $2 \mathrm{lb}$. in weight in two days; cyanosis of the hands was noted. He was thought to have a haemolytic infection, and was treated with 


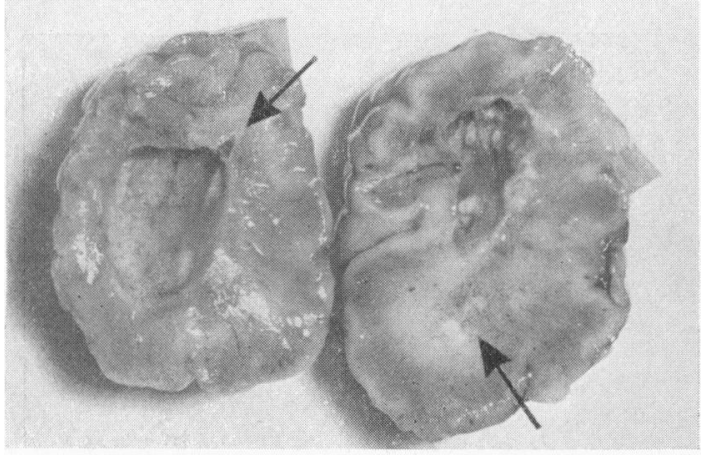

FIG. 1.

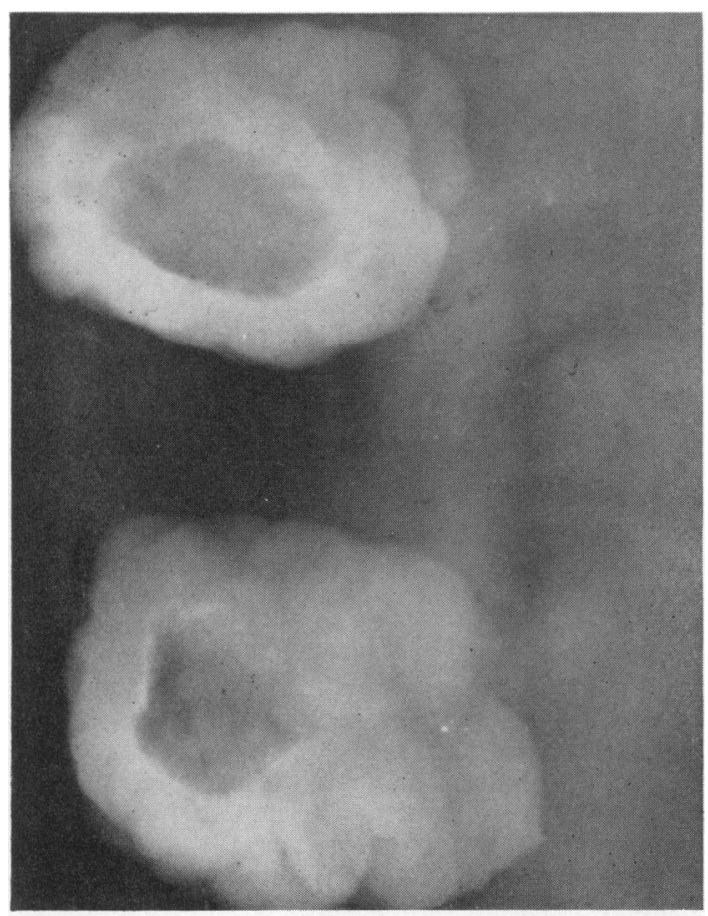

FIG. 2.

FIG. 1.-Case 1: Coronal section of frontal poles of brain showing periventricular necrosis and ependymal erosion (arrow). Isolated necrosis is present in centrum ovale (arrow).

FIG. 2.-Case 1: Radiograph of cerebral slices; calcification outlines the immediate walls of the lateral ventricle.

Fig. 3.-Case 1: Wall of lateral ventricle showing absence of ependyma. Encephalomalacia of superficial matrix is present with mild lymphocytic reaction. A deeper layer of calcification is seen without reaction. Note the cytomegalic inclusion body (arrow). (Haematoxylin-phloxin-saffron $\times 31$.)

Fig. 4.-Case 1: Swollen calcified myelin fibres in periventricular necrotic zone, without host reaction. (Haematoxylin-phloxin-saffron $\times 314$ ).

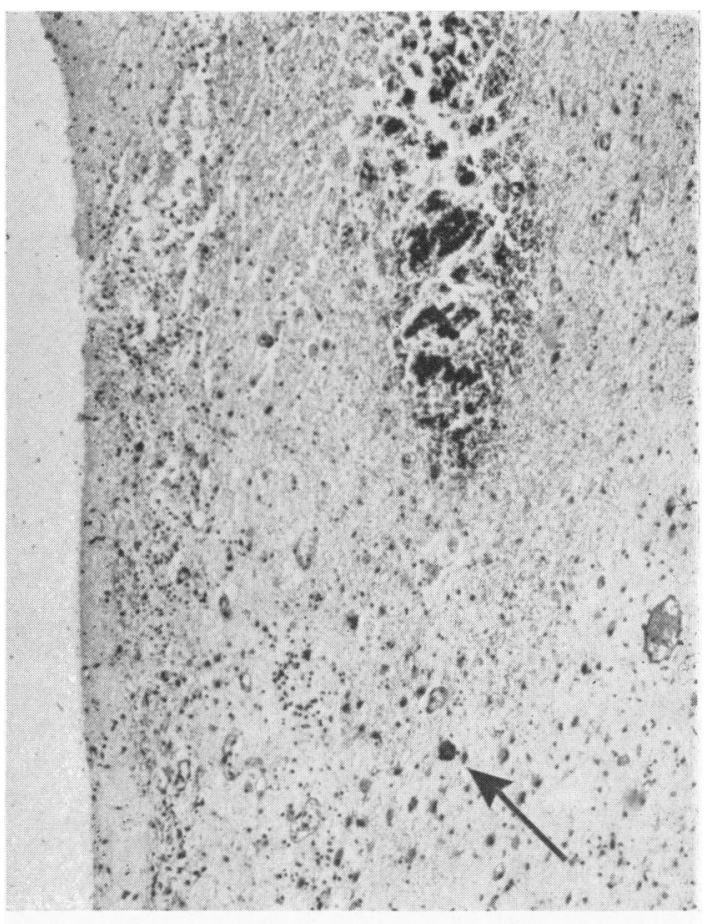

FIG. 3.

ต

믐

ڤ

$\overrightarrow{0}$

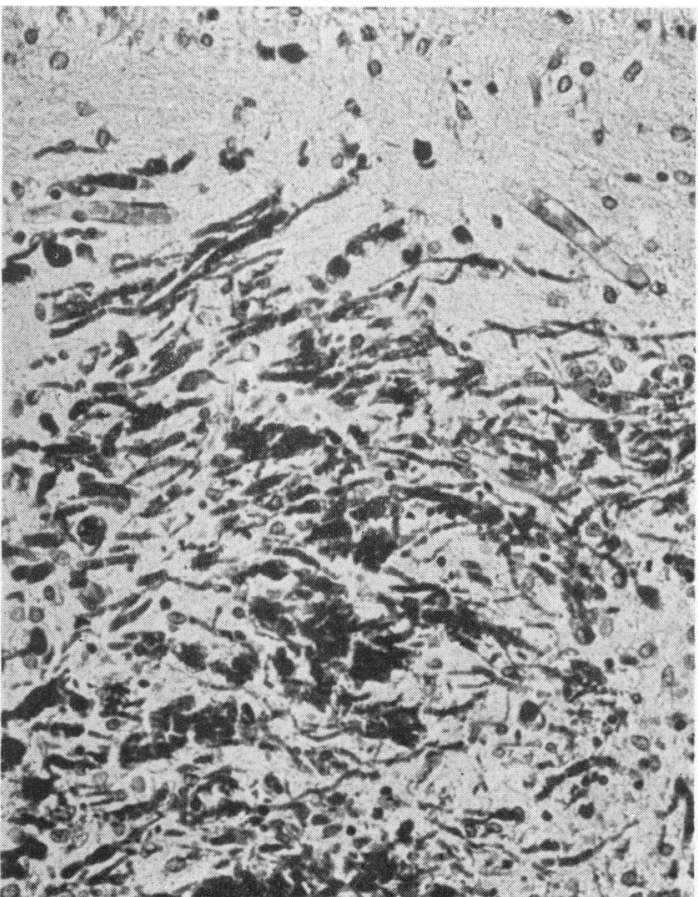

융 ?

흑 


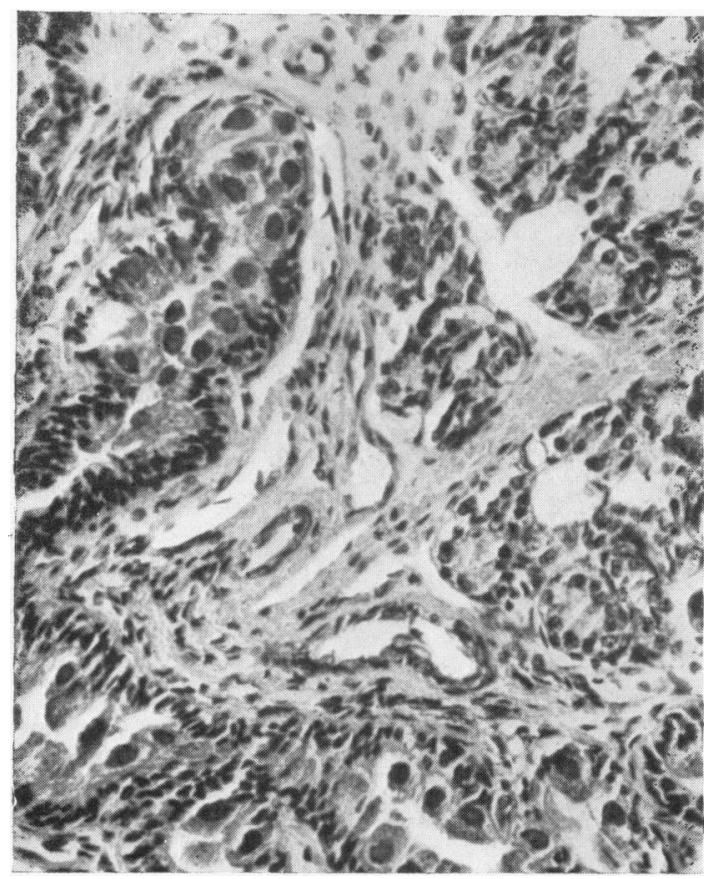

FrG. 5.-Case 1: Intracytoplasmic inclusion bodies are present in most parotid duct epithelial cells. (Haematoxylin-phloxin-saffron $\times 314$.)

chloramphenicol ('chloromycetin palmitate'). No abnormalities were noted on routine urinalysis, $\mathrm{Hb}$ was $11.9 \mathrm{~g} . / 100 \mathrm{ml}$., and no bacterial pathogens were isolated from stools. Fifteen days after birth the child became dyspnoeic, cyanosed, and died.

Autopsy showed only irregular yellow areas of necrosis in the centrum ovale, lightly scattered through the cerebral hemispheres (Fig. 7). Microscopically, sub-

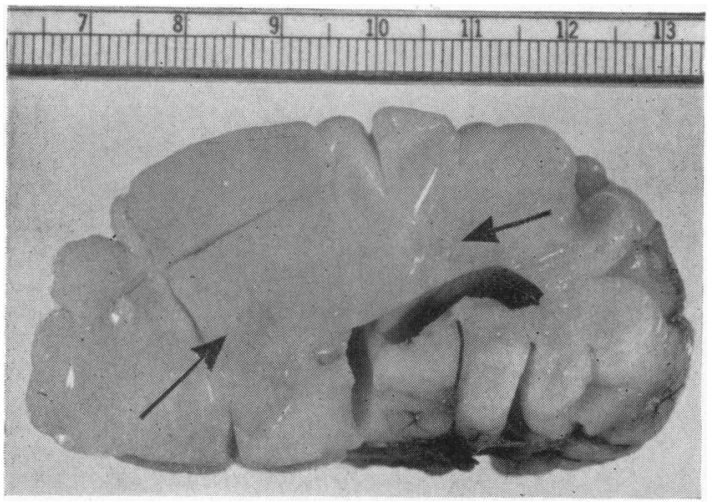

FIG. 7.-Case 2: Parasagittal section of right cerebral hemisphere showing foci of necrosis in periventricular matrix (arrow).

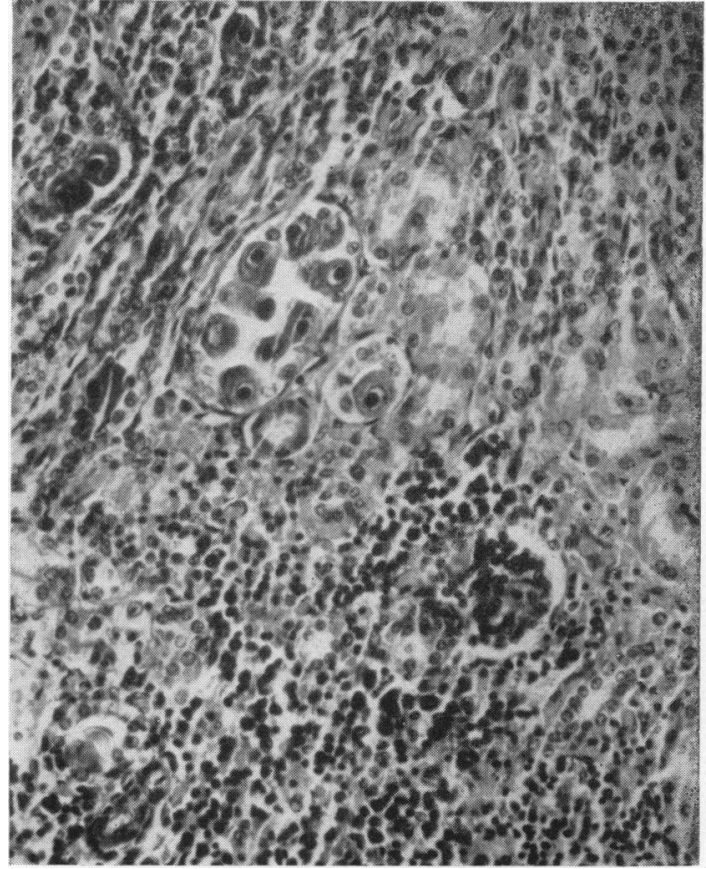

FIG. 6.-Case 1: Intramuscular inclusion bodies with a distinct 'owl-eye' halo are shown in renal convoluted tubule epithelial host cells. Interstitial nephritis is present. (Haematoxylin-phloxin-saffron $\times 314$.)

ependymal necrosis was very extensive in the lateral ventricles and resembled Case 1 in detail, except that ependymal ulceration had not yet occurred. Radiographs revealed no demonstrable calcification in brain slices. Occasional cytomegalic inclusion bodies were found near these necrotic areas, but the brain stem, cerebellum and cord were intact. The liver showed scattered canalicular bile plugs, but no other changes apart from infrequent cytomegalic inclusion bodies. No other abnormalities were seen in other tissues. The mother could recall no symptoms of illness during pregnancy.

Case 3.-A 22-year-old healthy gravida-2 produced a full-term baby girl weighing $6 \mathrm{lb} .8 \mathrm{oz}$; the delivery was uncomplicated. The infant fed well, but within a few hours small subcutaneous bruises appeared spontaneously over the entire body, especially in the scalp, followed by a coarse ecchymotic rash. On the following day laboratory investigations showed the child's total serum bilirubin to be $7 \cdot 3 \mathrm{mg} . / 100 \mathrm{ml}$. (normal $0 \cdot 2$ $0.8 \mathrm{mg} . / 100 \mathrm{ml}$.), direct reacting component of $0.3 \mathrm{mg}$./ $100 \mathrm{ml}$. (normal 0. 0-0. $2 \mathrm{mg} . / 100 \mathrm{ml}$.), $\mathrm{Hb} 16 \cdot 8 \mathrm{~g} . / 100 \mathrm{ml}$., white blood cells 21,000 per c.mm. with polymorphs $82 \%$, metamyelocytes $2 \%$, lymphocytes $16 \%$, and only occasional normoblasts in the film. The platelet count was 60,000 per c.mm. Jaundice became clinically apparent on the following day when total serum bilirubin 


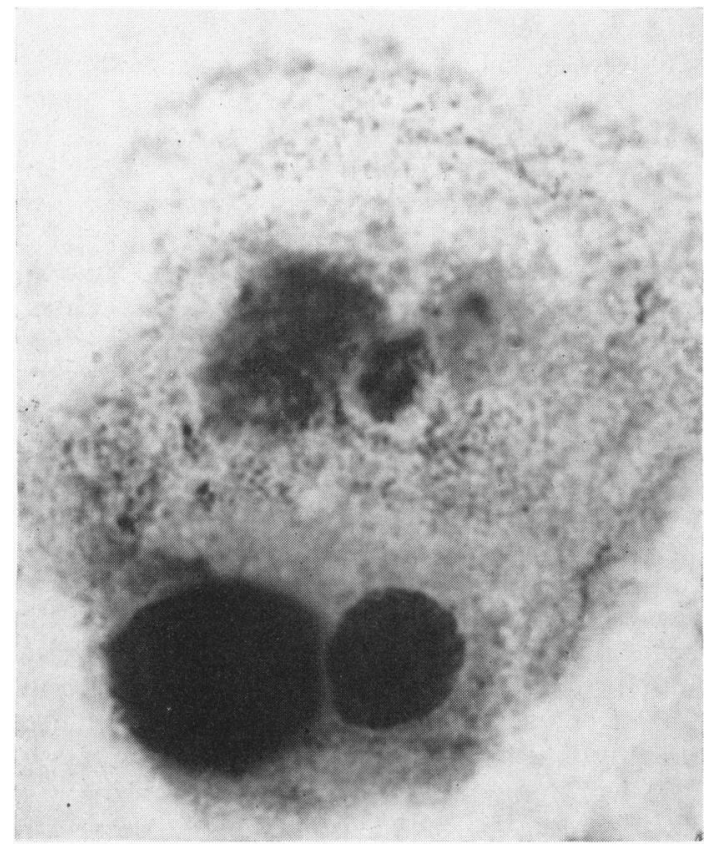

FIG. 8.-Case 3: Wright's stained urine cell sediment showing a cytoplasmic inclusion body larger than the host cell nucleus.

had risen to $12.8 \mathrm{mg} . / 100 \mathrm{ml}$. The platelet count remained unchanged; the infant remained afebrile and was feeding well, but showed some reduction in activity. Films of sediment from centrifuged fresh urine showed four cytomegalic inclusion bodies (Fig. 8). No intracerebral calcification was detectable on skull films. $\mathrm{Hb}$ fell to 15.9 g. $/ 100 \mathrm{ml}$., but blood films still showed only occasional normoblasts and the Coombs test remained negative. The mother and baby were both group A CD positive $\mathrm{E}$ negative.

In the first day and a half of life $7.5 \mathrm{mg}$. of vitamin $\mathrm{K}$ analogue had been given intramuscularly, but after the demonstration of urinary cytomegalic inclusion bodies this was discontinued, and hydrocortisone sodium succinate $5 \mathrm{mg}$. was given intramuscularly every six hours. The total daily dose was serially reduced from $20 \mathrm{mg}$. to $4 \mathrm{mg}$. by the fifteenth day when it was discontinued. Cytomegalic inclusions were seen in cells of urinary sediment for four days. The platelet count remained unchanged for the first five days of treatment, then gradually rose to 340,000 per c.mm. by the eighth day of life. Total serum bilirubin reached a maximum of $14.9 \mathrm{mg} . / 100 \mathrm{ml}$. on the fifth day and thereafter declined into normal ranges after the eighth. No occult blood was found in the stools on any day. On close questioning the mother had no recollection of illness during pregnancy or confinement. Daily samples of her urine taken during the child's jaundice did not show cytomegalic inclusion bodies in stained cell sediments. The baby has remained well during nine months of observation.
The mother was not alarmed by purpura in this child, and explained that 15 months previously her first-born had shown very similar illness in another hospital. A few petechiae were noted in her skin at birth. These increased rapidly in number in the first hours, reaching several $\mathrm{mm}$. in diameter on the trunk and limbs. This child was group A CD positive E negative, direct Coombs test was negative, red blood cells were 6,700 per c.mm., white blood cells 19,900 per c.mm. with no erythroblastosis on blood films. Platelet count was 72,000 per c.mm., bleeding time one and a half minutes and clotting time three minutes. On the following day urine examination for cytomegalic inclusion bodies was negative, but the platelet count had fallen to 40,000 per c. $\mathrm{mm}$. with a total serum bilirubin of $5.6 \mathrm{mg} . / 100 \mathrm{ml}$, including $0.3 \mathrm{mg} . / 100 \mathrm{ml}$. of direct reacting type. The infant was given triamcinolone $1 \mathrm{mg}$. four hourly by mouth with serially reducing doses; this was discontinued 10 days later. The platelet count fell below 38,000 per c.mm. for the first four days when mild jaundice was evident, then rose abruptly to 220,000 per c.mm. and stayed within normal range thereafter. Radiographs of the skull were not taken during this illness, and the child is without evidence of retardation.

\section{Discussion}

Characteristic owl-eye inclusion bodies producing cytomegaly were first recorded in renal tubular epithelium as a microscopic curiosity by Jesionek and Kiolemenoglou (1904). For many years considered to be harmless protozoan-like structures, they were found coincidentally in intact salivary and lachrymal gland epithelium in more than $10 \%$ of all infant autopsies (Farber and Wolbach, 1932). Viral aetiology was suspected late and not proven until 1956 (Smith, 1956).

Wyatt, Saxton, Lee and Pinkerton (1950) showed that 'salivary gland virus', long thought to be quite harmless, caused fatal illness in the newborn, mimicking erythroblastosis, but associated with haemorrhagic tendencies and thrombocytopenic purpura. Some cases show periventricular cerebral necrosis, and even chorioretinitis simulating toxoplasmosis (Guyton, Ehrlich, Blanc and Becker, 1957). Others with radiologically demonstrable periventricular cerebral calcification have subsequently become hydrocephalic (Sackett and Ford, 1956; Guyton et al., 1957), or show focal cerebral and cerebellar microgyria (Diezel, 1954).

Infants surviving the fulminating disease sometimes succumb in the following months to refractory interstitial pneumonitis, necrotizing focal hepatitis (Medearis, 1957), or Addison's disease (Bacala and Burke, 1953), depending upon the organs which bear the brunt of viral infection. This illustrates the susceptibility of immature tissues to viral injury 
which produces characteristic necrosis and little host response.

The infection appears to be largely harmless outside infancy. It is seldom diagnosed as a cause of disease in adults except for rare instances of primary refractory fibrosing pneumonitis (Fisher and Davis, 1958) or coexisting with pneumocystis carinii infection (Williams, Stretton and Leonard, 1960). It occurs occasionally in terminal lymphomatosis where normal antibody mechanisms are assumed to be severely damaged (Delvaux, 1957). Whether this represents reactivation or superinfection is unknown. It has also been thought to occur after suppression of antibody mechanisms by steroids used to treat lymphomata. However, association of the disease with similar steroid therapy in patients with rheumatoid arthritis has not been reported. Fisher and Davis (1958) recorded one case of refractory fibrosing pneumonitis, attributed to cytomegalic salivary gland virus in an adult, which did not respond to A.C.T.H. or cortisone. On the other hand, the only two diagnosed neonatal cases who survived without residual defects were treated with cortisone and prednisolone respectively (Margileth, 1955; Birdsong, Smith, Mitchell and Corey, 1956). After hydrocortisone therapy Case 3 showed rapid improvement and no relapse. It is difficult to assess these sporadic observations, for the natural history of this disease is not fully known. In infancy the icteric and purpuric type of disease is usually fulminating and does not often appear to be self-limiting (Medearis, 1957). Surprisingly, specific antibodies of neutralizing and complementfixing type have been detected in the bloods of $81 \%$ of the general population over 35 years of age, with smaller proportions in younger persons (Rowe, Hartley, Waterman, Turner and Huebner, 1956).

Such observations led to a search for reservoirs of infection. Initially, similar cytomegalic inclusion bodies were found in the salivary glands of many small animals (Farber and Wolbach, 1932; Lancet, 1957). However, these viruses have all been shown to be strictly species-specific, and while they do cause interstitial pneumonitis, e.g. in immature guinea-pigs and rats, there is no evidence that they play any part whatever by cross-infection to humans (Kuttner and T'ung, 1935).

Birdsong et al. (1956) suggested that the newborn cases must receive salivary gland virus in utero from a primary subclinical infection of the mother during pregnancy. Certainly no inclusion bodies have been demonstrated in the placenta of affected infants at birth, and absence of maternal illness in late pregnancy has been the rule. The spectacular 'onset' of icteric illness in the child so shortly after birth is probably illusory and due to the abrupt removal of the superior bilirubin-excreting and hepatic anticoagulant mechanisms of the mother, which throw the diseased infant upon its own resources, as in erythroblastosis.

The haemorrhagic and thrombocytopenic manifestations confined to the child are unexplained. Despite jaundice there is little evidence that they are due to a haemolytic component. In Cases 1 and 3 no signs of haemolysis were seen on blood films, and the prothrombin time in the latter was prolonged. Thrombocytopenia could well result from platelet adhesion in the spontaneous haemorrhages from hepatic injury, which often precede purpura. The apparent predilection of this virus for salivary glands and renal tubules is relative, for inclusions have been found in almost every tissue. The characteristic inclusion bodies have been demonstrated in gastric washings (Blanc, 1957), subdural fluids (Arey, 1954), but more usefully from a diagnostic view in cells from fresh urine sediment (Fetterman, 1952).

It has been suspected that salivary gland virus infection of the foetus occurs long before birth and often produces progressive cerebral injury for several months in utero. In a detailed study of cytomegalic inclusion disease in a newborn infant, Diezel (1954) found that there was microgyria of earlier myelinating parts of the cerebral cortex, e.g. the regions of central sulcus and the island of Reil, with failure in development of zones myelinating later. This led Diezel to believe that the necrotic processes had begun close to the end of the third month of foetal life. Haymaker, Girdany, Stephens, Lillie and Fetterman (1954) showed that the curious localization of viral injury to subependymal regions of the lateral ventricles was probably due to marked susceptibility of very active foetal tissues. In contrast with the remainder of the ventricular system, the periventricular matrix of the lateral ventricles is still highly active at the end of the third month of foetal life. In other words, the foetal central nervous system is most susceptible during its period of maximum growth and especially in zones which take longest to mature.

Case 2 showed advanced cerebral lesions at six months gestation. This is the first confirmatory observation of Diezel and Haymaker's deductions that salivary gland virus infection of the foetal brain dates from the fourth month, or later, of foetal life.

Little information is available on the duration of the carrier states in such children or their mothers. In a most interesting case which had been detected six weeks after birth by Fetterman's first demon- 
stration of characteristic inclusion bodies in stained cells of urine sediments (1952), Guyton et al. (1957) showed that the virus could still be grown from ocular aqueous. Guyton adds 'the virus could still be grown from the patient's urine at nine months of age and many inclusion cells were consistently demonstrated in the stained urine sediment'. Most cases have been reported as affecting only first-born children. This led to a belief that any carrier state of the mother must be of transient nature. The probable occurrence in the sibling of Case 3 suggests that, as in Guyton's child, the period of passive carriage may be much longer. So far as we are aware, the infection has not been reported in more than one child of a given mother apart from twins (Bellamy, 1954). Smith and Vellios (1950) mention an example in a fourth child. Rowe et al. (1956) have been able to grow salivary gland virus from human adenoidal tissues. However, investigation of carrier states remains a field for further study.

Demonstration of an increasing incidence of specific antibodies by age in bloods of the general population (Rowe et al., 1956), and the frequency of characteristic cells in infants, suggest that infection of most females occurs before child-bearing age. If lack of primary maternal salivary gland virus infection until early pregnancy leads to a risk of severe foetal brain damage in utero, deliberate exposure of female children seems worth while, as in rubella, for infection appears largely harmless outside infancy.

\section{Summary}

Three cases of cytomegalic inclusion disease are reported, two in premature infants with advanced periventricular cerebral necrosis. These are the first confirmatory observations of the suspicion that this virus infection of foetal brain occurs quite early in utero. Cytomegalic salivary gland virus infection appears largely harmless outside infancy but remains a risk to the foetus if first contracted by the -mother during pregnancy. This disease appears to be a potentially preventable cause of mental defect and cerebral malformation which, because they are congenital, are often regarded as unavoidable disasters of heredity.

We are indebted to Dr. N. Goluboff, City Hospital, Saskatoon, Canada, for details of the sibling briefly recorded after Case 3.

\section{REFERENCES}

Arey, J. B. (1954). Cytomegalic inclusion disease in infancy. Amer. J. Dis. Child., 88, 525.

Bacala, J. C. and Burke, R. J. (1953). Generalized cytomegalic inclusion disease. J. Pediat., 43, 712.

Bellamy, J. (1954). Cytomegalic inclusion-body disease occurring in twins. Amer. J. clin. Path., 24, 1040.

Birdsong, McL., Smith, D. E., Mitchell, F. N. and Corey, J. H. (1956). Generalized cytomegalic inclusion disease in newborn infants. J. Amer. med. Ass., 162, 1305.

Blanc, W. A. (1957). Cytologic diagnosis of cytomegalic inclusion disease in gastric washings. Amer. J. clin. Path., 28, 46.

Delvaux, T. C. (1957). Viral lesions complicating lymphoma in adult: localised cytomegalic inclusion disease and a second viral infection. ibid., 28, 286.

Diezel, P. B. (1954). Mikrogyrie infolge cerebraler Speicheldrüsenvirusinfektion im Rahmen einer generalisierten Cytomegalie bei vinem Säugling. Zugleich ein Beitrag zur Theorie der Windungseinem Säugling. Zugleich ein Beitrag zur Theorie
bildung. Virchows Arch. path. Anat., 325, 109.

Farber, S. and Wolbach, S. B. (1932). Intranuclear and cytoplasmic inclusions ('Protozoan-like bodies') in salivary glands and other organs of infants. Amer. J. Path., 8, 123.

Fetterman, G. H. (1952). A new laboratory aid in the clinical diagnosis of inclusion disease of infancy. Amer. J. clin. Path. $22,424$.

Fisher, E. R. and Davis, E. (1958). Cytomegalic-inclusion disease in the adult. New Engl. J. Med., 258, 1036.

Guyton, T. B., Ehrlich, F., Blanc, W. A. and Becker, M. H. (1957). New observations in generalized cytomegalic-inclusion disease New observations in generalized cytomegalic-inclusion disease
of the newborn. Report of a case with chorioretinitis. ibid., of the new
257,803 .

Haymaker, W., Girdany, B. R., Stephens, J., Lillie, R. D. and Fetterman, G. H. (1954). Cerebral involvement with advanced periventricular calcification in generalized cytomegalic inclusion disease in the newborn. J. Neuropath. exp. Neurol., 13, 562.

Jesionek, A. and Kiolemeno, slou, B. (1904). Uber einen Befund von protozoënartigen Gebilden in den Organen eines hereditärleutischen Fötus. Münch. med. Wschr., 51, 1905.

Kuttner, A. G. and T'ung, T. (1935). Further studies on submaxillary gland viruses of rats and guinea pigs. J. exp. Med. 62,805 .

Lancet (1957). Cytomegalic inclusion disease (Annotation). Lancet, 1,627 .

Margileth, A. M. (1955). Diagnosis and treatment of generalized cytomegalic inclusion disease of newborn. Pediatrics, 15, 270.

Medearis, D. N. (1957). Cytomegalic inclusion disease. An analysis of the clinical features based on the literature and six additional cases. ibid., 19, 467.

Rowe, W. P., Hartley, J. W., Waterman, S., Turner, H. C. and Huebner, R. J. (1956). Cytopathogenic agent resembling human salivary gland virus recovered from tissue cultures of human adeno:ds. Proc. Soc. exp. Biol. (N.Y.), 92, 418.

Sackett, G. L. and Ford, M. M. (1956). Cytomegalic inclusion disease with calcification outlining the cerebral ventricles. Amer. J. Roentgenol., 76, 5.12.

Smith, M. G. (1956). Propagation in tissue cultures of a cytopathogenic virus from human salivary gland virus (S.G.V.) disease. Proc. Soc. exp. Biol. (N.Y.), 92, 424.

and Vellios. F. (1950). Inclusion disease or generalized salivary gland virus infection. Arch. Path. (N.Y.), 50,862.

Williams, G. Stretton, T. B. and Leonard, J. C. (1960). Cytomegalic inclusion disease and pneumocystis carinii infection in an adult. Lancet, 2, 951.

Wyatt, J. P., Saxton, J., Lee, R. S. and Pinkerton, H. (1950) Generalized cytomegalic inclusion disease. J. Pediat., 36, 271. 